\title{
Spektrum didaktických řídicích stylů ve výuce tělesné výchovy na 2. stupni základní školy
}

\section{Teaching styles in lower-secondary physical education lessons}

\author{
Jiří Sliacky, Marcela Janíková
}

\author{
Fakulta sportovních studií, Masarykova univerzita, Brno
}

\begin{abstract}
Abstrakt
Přispěvek přináši výsledky empirické studie využivání didaktických ř́dicích stylů v tělesné výchově na 2. stupni základní školy, jejímž cílem bylo zjistit, jaké didaktické ř́dicí styly učitelé ve výuce reálně využivají. Jako metoda sběru dat byla použita videostudie, pořizené videozáznamy vyučovacích jednotek byly kódovány podle uvedeného kategoriálního systému a následné vyhodnocení bylo provedeno prostřednictvím relativních četností zjištěných kategorií. Výsledky analýzy ukázaly, že učitelé ve výuce využivali pouze př̀ikazový a praktický didaktický ř́dicí styl, což je v textu dále diskutováno na základě hlubši analýzy námi zjištěných výsledki a výsledků některých zahraničních výzkumů.
\end{abstract}

\begin{abstract}
In the paper, results are presented of empirical research on teaching styles used in physical education lessons in lower-secondary schools, which aimed to analyse everyday instruction and show which teaching styles are used. The method of video study was employed to generate data, which were later coded by means of a system of categories. The findings show that in the analysed lessons, the teachers only used the "command" and the "practice" styles. These findings are discussed in the context of further analysis of the research results and also in the context of other research carried out outside of the Czech Republic.
\end{abstract}

Klíčová slova: Videostudie, didaktický ř́dicí styl, kategoriálni systém, tělesná výchova.

Key words: Video study, teaching style, system of categories, Physical Education.

Studie byla zpracována v rámci řešeni projektu GA ČR P407/11/0262 Kvalita kurikula a výuky v oborech školního vzdèlávání.

\section{ÚVOD}

Vyučování je nejčastěji nahlíženo jako záměrná činnost realizovaná v interakci učitele a žáka, která vede k učení (srov. nap̌r. Mareš, Průcha, \& Walterová, 2003, s. 288). V souladu s tímto pojetím můžeme vyučování logicky chápat jako proces, při kterém učitel cíleně vytváří pro své žáky příležitosti, v nichž se zamýšlené učení realizuje. Toto teoretické východisko - vyučování jako vytváření příležitostí k učení - se stalo i výchozím konceptem videostudie tělesné výchovy (Janíková et al., 2008, s. 94), která je realizována ve spolupráci Institutu výzkumu školního vzdělávání Pedagogické fakulty MU Brno, Katedry pedagogiky sportu Fakulty sportovních studií MU Brno a Katedry tělesné výchovy Pedagogické fakulty MU Brno.

\section{Videostudie tělesné výchovy}

Uvědomování si, jaké př́ležitosti k učení jsou dnešním žákům nabízeny a jaká je jejich kvalita a kvantita, je součástí pedagogických výzkumů zaměřených především na kvalitu výuky a její didaktické aspekty. Videostudie, jakožto výzkumná technika, založená na analýze videozáznamu výuky, nepochybně má pro tuto oblast (ale samozřejmě nejen pro ni) značný potenciál. Ten spatřujeme především ve schopnosti plnohodnotně a reálně zprostředkovat výzkumníkovi samotný průběh vzdělávacího procesu. Ten jej pak může následně analyzovat i reanalyzovat $\mathrm{z}$ různých aspektů výuky, digitálně jej dále zpracovávat a využívat možnosti, aby na zkoumané situace nahlíželo více výzkumníků - pozorovatelů. Janík a Miková proto charakterizují 
videostudii jako „komplexní metodologický postup, v jehož rámci se může uplatnit celá řada různých metod a technik sběru a analýzy videodat“ (2006, s. 13).

Cílem videostudie tělesné výchovy (dále jen „TV“) bylo analyzovat vyučovací jednotky TV na 2. stupni základní školy (dále jen „ZŠ“). Výše zmíněný výchozí teoretický koncept videostudie je v obecné rovině pojímán jako systém určitých výzev, podněcující žáky k tomu, aby se zabývali učivem. Výzkum těchto podnětů je potom z obecně didaktického pohledu zaměřen na aspekty výuky, které jdou např́č celým kurikulem základního vzdělávání (nap̌r. organizační formy a fáze výuky). Z pohledu didaktiky TV je ale pozornost přenesena i na specifické oborově didaktické aspekty výuky, které zohledňují právě zvláštnosti výuky TV (Janíková et al., 2008, s. 96). Jedním z těchto oborově didaktických aspektů jsou didaktické ř́ídicí styly (dále jen „DŘS“) podle teorie Mosstona a Ashworthové (2008), jejichž analýze se budeme věnovat v tomto př́íspěvku.

Ačkoli výsledky této analýzy tvoří ryze deskriptivní statistické údaje, záměrně je dále v naší studii uvádíme do širších souvislostí i s již zmiňovanou kvalitou výuky ${ }^{1}$. Jsme totiž přesvědčeni, že tato jejich širší interpretace otevírá další důležité otázky, jejichž následné řešení může přispět ke zkvalitňování vzdělávacího procesu v TV.

\section{Spektrum didaktických řídicích stylů - výběr z teorií}

Jestliže učitel předkládá $\mathrm{v}$ rámci vyučování svým žákům výzvy, kterými se je snaží podněcovat k tomu, aby se zabývali učivem, potom musí za tímto účelem podniknout řadu rozhodnutí. Rozhoduje se o tom, jaké učivo vybere, prostřednictvím jakých aktivit jej bude realizovat, jakým způsobem budou aktivity prováděny atd. Prostor pro činění rozhodnutí je pak samozřejmě i na straně žáka. A právě poznání, že vyučování je řetězcem rozhodnutí, vedlo pedagoga a sportovního nadšence Mosstona k objevu spektra didaktických řídicích stylů (v originále Spectrum of Teaching Styles). Tuto teorii pak prvně publikoval již v roce 1966 ve své knize „Teaching Physical Education“.

Autor sám, později společně se svou kolegyní Ashworthovou, spektrum popisuje jako rámec, který vymezuje rozsah možností existujících v rámci vyučování a učení, určuje jedinečné cíle každé volby, identifikuje soubor rozhodnutí, která musí být ze strany učitele a žáků učiněna pro jejich dosažení, poskytuje řadu možností pro posouzení učiva a pomáhá učiteli porovnat míru shody mezi jeho záměrem a reálným provedením (Mosston \& Ashworth, 2008, s. 6). Dobrý charakterizuje spektrum jako konfiguraci „vybraných rozhodnutí, která po zralé úvaze vytvářejí podmínky pro učení“ (2007, s. 10) a dále vystihuje jeho podstatu, spočívající v postupném přesouvání rozhodování z učitele na žáka, čímž dochází ke snížení závislosti žáka na učiteli a tedy ke zvýšení jeho samostatnosti (2007, s. 11).

Spektrum zároveň poskytuje jasný koncept a rovněž společný jazyk, který stírá veškeré prŕípadné komunikační bariéry. Učitelům tělesné výchovy, trenérům a dalším sportovním pedagogům tak může sloužit i jako jakési společné ,úložišsěc“ poznání o učení a nástroj pro jeho další zkoumání (Goldberger, 2011, s. 2).

Spektrum je tvořeno $11 \mathrm{DŘS}$, z nichž každý představuje uspořádání proměnných, tedy ř́́dicí činnosti učitele a činnosti žáka s ohledem na dosahování specifických výchovně vzdělávacích cílů (Dobrý, 1988, s. 93). Jednotlivé styly jsou dále seskupeny do dvou hlavních skupin podle toho, zda jsou určeny pro reprodukování již známého obsahu (tzv. reprodukční styly), nebo produkování zcela nového (tzv. produkční styly). Hranici mezi těmito dvěma skupinami Mosston a Ashworthová pojmenovali „discovery threshold“, neboli kognitivní práh. Strukturu spektra přibližuje obrázek 1. Jeho hlavní myšlenky bychom tedy mohli shrnout do následujících bodů:

- spektrum vymezuje řetězec voleb existujících během vyučování a učení a určuje jedinečné cíle každé volby,

- spektrum určuje specifickou sadu rozhodnutí, která musí být učiněna při každé volbě učitelem a žákem, má-li být dosaženo konkrétního cíle,

- spektrum slouží jako model, který pomáhá dosáhnout shodu mezi záměrem a činností,

- spektrum zásobuje učitele základními teoretickými vědomostmi důležitými pro tvorbu učebního prostředí a žákům nabízí celou škálu edukačních příležitostí.

Cílem spektra je tedy ukazovat učitelưm různé možnosti změn, nikoli směřovat jejich vyučování $\mathrm{k}$ jednomu rigidnímu chování (Dobrý, 2007, s. 10).

1 Tato studie byla zpracována v rámci řešení projektu GA ČR P407/11/0262 Kvalita kurikula a výuky v oborech školního vzdělávání. 


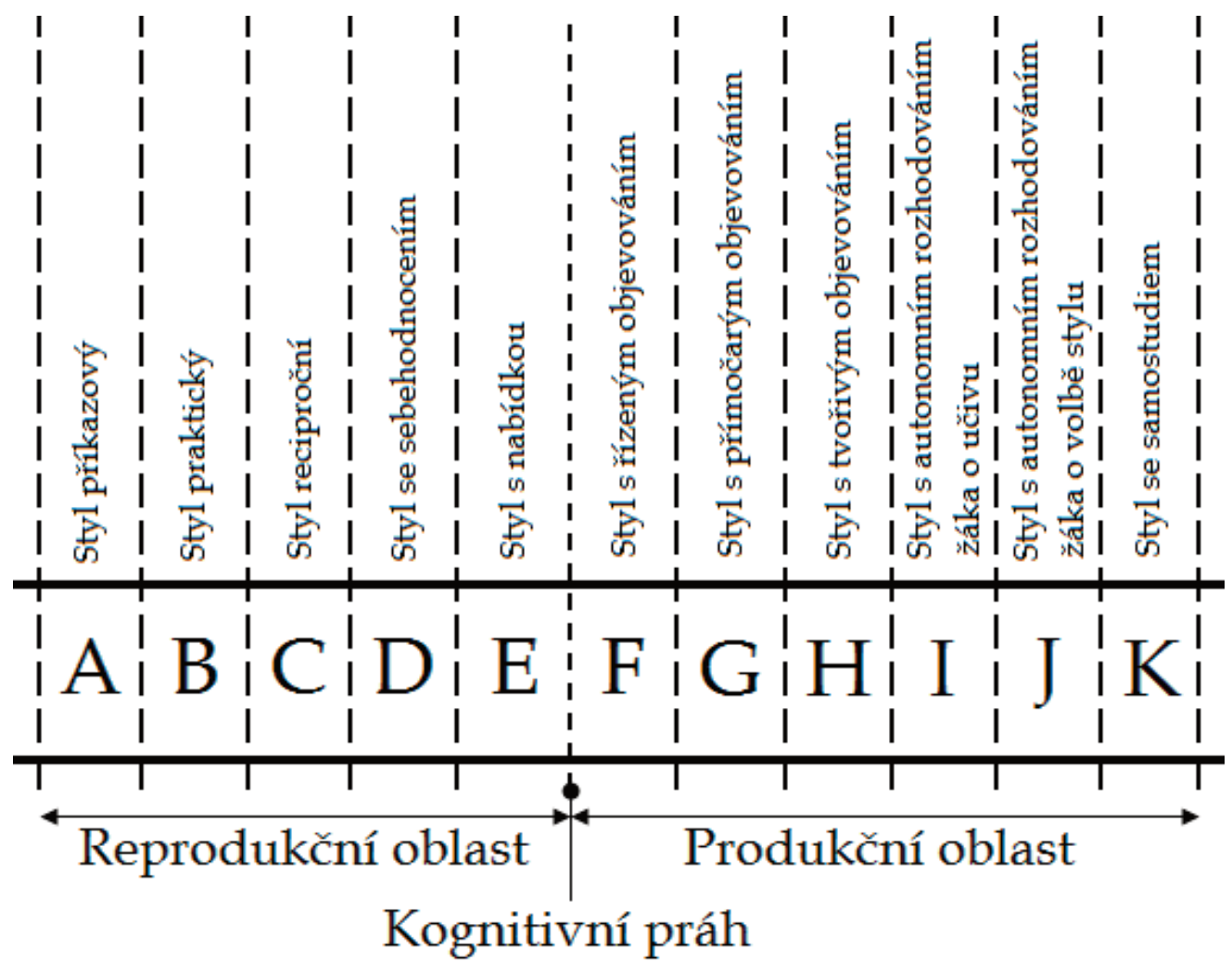

Obr. 1. Struktura spektra didaktických rídicich stylü

Jednotlivé DŘS jsou komplementární, žádný není univerzální, žádný není lepší než druhý (Dobrý, 2007, s. 11). Každý styl je zkrátka jedinečný tím, jaké cíle umožňuje naplňovat. Jedenáct definovaných DŘS však označuje na spektru jen jakési mezníky, oddělující postupy, vedoucí k významně odlišným vzdělávacím cílům. Bývají proto někdy označovány jako tzv. mezní styly. Mezi nimi se však nachází řada dalších stylů, tvořících přechod od jednoho stylu ke druhému, které vytváŕí další vzdělávací možnosti a varianty. Tyto tzv. přechodové styly nejsou přímo definovány a na základě své struktury a cílů jsou přidružovány ke konkrétnímu meznímu stylu (Mosston \& Ashworth, 2008, s. 13). Základní charakteristiky prvních deseti mezních stylů spektra (označovaných písmeny A - J), které byly předmětem našeho výzkumu, odpovídají obsahovému vymezení kategorií kategoriálního systému pro kódování DŘS (viz tabulka 2, kategorie 1 - 10). Jedenáctý DŘS se samostudiem (označovaný písmenem K) do našeho výzkumu nebyl zahrnut a v kategoriálním systému tedy není uveden, nebot' jak Mosston a Ashworthová uvádějí, jedná se o styl, který neexistuje v prostředí školních učeben (2008, s. 290), což neodpovídá zaměření našeho výzkumu.

\section{METODIKA}

\section{Cíle výzkumu}

Na začátku výzkumu jsme si položili tři výzkumné otázky:

1. Jak široké spektrum DŘS je využíváno při výuce TV na 2. stupni ZŠ?

2. Jaké DŘS jsou ve výuce využívány nejčastěji?

3. Liší se složení využívaného spektra DŘS s ohledem na délku praxe učitele, pohlaví učitele, pohlaví žáků nebo velikost školy?

Hlavním cílem našeho výzkumu tedy bylo identifikovat pomocí analýzy videozáznamů vyučovacích jednotek TV, které DǨS učitelé využivají při výuce TV na 2. stupni ZŠS.

\section{Charakteristika výzkumného souboru}

Při výběru výzkumného vzorku bylo prvotním záměrem pracovat s náhodně vybranými učiteli v České 
republice. To se však následně ukázalo $\mathrm{z}$ technických důvodů jako neproveditelné a náhodný výběr byl tudíž uplatněn jen na úrovni školy $(Z S ̌)$. Z důvodu dostupnosti pro výzkumné pracovníky byl výběr omezen i regionálně na Jihomoravský, Olomoucký a Zlínský kraj. Protože téměř 50 \% ZŠ v těchto regionech je umístěno v malých obcích (méně jak 1500 obyvatel), byl náhodný výběr vážen podle velikosti sídla, ve kterém se škola nachází, aby bylo zastoupení velkých a malých škol přiměřené. Pomocí generátoru náhodných čísel (počítačový software Statistica 7.1) bylo následně vybráno 45 ZŠ, z nichž 15 bylo pro svoji neúplnost, malotř́dní systém či speciální zaměření vyřazeno. Zbývající pak byly osloveny, aby se do projektu videostudie TV zapojily. Nabídku nakonec přijalo 19 škol, z toho 9 škol z Jihomoravského, 5 ze Zlínského a 5 z Olomouckého kraje.

Jak ukazuje tabulka 1, počet učitelů, kteří se z uvedených škol do projektu zapojili, byl 20, přičemž 10 $\mathrm{z}$ nich byli muži a 10 ženy. V rámci projektu bylo natočeno celkem 58 vyučovacích jednotek $(51 \mathrm{z}$ nich o délce 45 minut a 7 o délce 90 minut).

Často diskutovaným problémem vyučovacích jednotek zaznamenaných na video, je jejich autentičnost. Mohou být totiž do jisté míry zkresleny sociální „žádoucností“ (učitel předvádí „ideální“ hodinu), nebo mohou být, díky přítomnosti kamery, „,nepovedené“ (učitel je nervózní, žáci se „předváději“). Autentičnost natočených vyučovacích jednotek tak byla v rámci videostudie monitorována pomocí dotazníků, které učitelé po každé vyučovací jednotce vyplňovali. Vyhodnocením těchto dotazníků bylo zjištěno, že více jak 95 \% vyučovacích jednotek učitelé označili jako typické nebo spíše typické, v 90 \% jednotek označili učitelé chování žáků za typické nebo spíše typické a v 98 \% se učitelé cítili velmi dobře, nebo byli jen mírně nervózní. Na základě těchto výsledků bylo možné konstatovat, že výuka př́tomností kamery narušena spíše nebyla (Janíková et al., 2008, s. 98 - 102). Celý dotazník je uveden v publikaci Janík a Miková (2006, s. 154).

Tab. 1. Učitelé zapojení do projektu videostudie tělesné výchovy (upraveno dle Janikové et al., 2009)

\begin{tabular}{|c|c|c|c|c|c|c|}
\hline Učitel & Pohl. & $\begin{array}{c}\text { Let } \\
\text { praxe }\end{array}$ & Aprobace & $\begin{array}{c}\text { Počet } \\
\text { jednotek }\end{array}$ & $\begin{array}{c}\text { Délky jednotek } \\
(\mathrm{min})\end{array}$ & $\begin{array}{c}\text { Počet žáků } \\
\text { školy }\end{array}$ \\
\hline Tv_A & 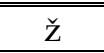 & 30 & Tv, Bv, ORv, Pč & 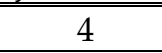 & $45+45+45+45$ & 720 \\
\hline Tv_B & Ž & 8 & Z, Tv, Psy & 4 & $45+45+45+45$ & 500 \\
\hline Tv_C & Ž & 22 & $\mathrm{Tv}, \mathrm{Bv}$ & 3 & $45+45+45$ & 160 \\
\hline Tv_D & Ž & 13 & 1.stupeň (+Hv) & 4 & $45+45+45+45$ & 140 \\
\hline Tv_E & $\mathrm{m}$ & 3 & $\mathrm{Tv}$ & 2 & $90+90$ & 730 \\
\hline Tv_F & $\mathrm{m}$ & 19 & $\mathrm{M}, \mathrm{Tv}$ & 3 & $45+45+45$ & 160 \\
\hline Tv_G & $\mathrm{m}$ & 28 & $\mathrm{Tv}, \mathrm{Z}$ & 2 & $45+45$ & 210 \\
\hline Tv_H & $\mathrm{m}$ & 4 & Tv, Př & 3 & $45+45+45$ & 500 \\
\hline Tv_I & $\mathrm{m}$ & 4 & $\mathrm{Tv}, \mathrm{Bi}$ & 2 & $90+90$ & 730 \\
\hline $\mathrm{Tv} \_\mathrm{J}$ & $\check{z}$ & 13 & $\mathrm{Tv}, \mathrm{Bi}$ & 2 & $90+90$ & 590 \\
\hline Tv_K & Ž & 3 & $\mathrm{Tv}$ & 3 & $45+45+45$ & 220 \\
\hline Tv_L & $\check{z}$ & 9 & $\mathrm{Tv}, \mathrm{Ov}$ & 3 & $45+45+45$ & 400 \\
\hline Tv_M & Ž & 2 & $\mathrm{Tv}$ & 4 & $45+45+45+45$ & 450 \\
\hline Tv_N & $\check{z}$ & 12 & Tv, Ped, Ped psy & 2 & $45+45$ & 650 \\
\hline Tv_O & $\mathrm{m}$ & 11 & $\mathrm{Tv}$ & 2 & $45+45$ & 650 \\
\hline Tv_P & $\mathrm{m}$ & 5 & studující Tv & 4 & $45+45+45+45$ & 200 \\
\hline Tv_Q & $\mathrm{m}$ & 44 & $\mathrm{Rj}, \mathrm{Ov}, \mathrm{Tv}$ & 2 & $45+45$ & 270 \\
\hline Tv_R & $\check{z}$ & 3 & $\mathrm{Tv}, \mathrm{Bi}$ & 3 & $90+45+45$ & 450 \\
\hline Tv_S & $\mathrm{m}$ & 5 & Př, studující Tv & 3 & $45+45+45$ & 490 \\
\hline Tv_T & $\mathrm{m}$ & 11 & $\mathrm{Tv}, \mathrm{Ch}$ & 3 & $45+45+45$ & 550 \\
\hline
\end{tabular}

\section{Metody sběru, zpracování a vyhodnocení dat}

Videostudii, jako metodu sběru dat, zařazujeme v systému metod pedagogického výzkumu do skupiny nezúčastněného pozorování, které lze, vzhledem ke kódování dle konkrétního kategoriálního systému, označit jako strukturované pozorování (srov. Průcha, 2006, s. 196).

Sběr dat prostřednictvím pořizování videozáznamů jednotlivých vyučovacích jednotek TV probíhal v období únor až červen 2007 (natáčení proběhlo celkem ve 44 dnech). Postup pořizování videozáznamu vyučovacích 
hodin byl sice standardizován (viz Janík \& Miková, 2006), ovšem vzhledem k variabilitě prostředí, ve kterém se TV odehrává (např. tělocvična, hřiště, plavecký bazén) a k jejím dalším specifikům (např. pohyb po relativně velkém prostoru, zvýšený přirozený hluk, stř́idání různorodých činností) bylo nutné tyto postupy mírně modifikovat. Každá vyučovací jednotka tak byla standardně natáčena dvěma kamerami, z nichž jedna snímala činnost učitele a druhá činnost co možná největšího počtu žáků. Zmíněné modifikace pak spočívaly hlavně ve dvou následujících bodech. Kamera snímající žáky nebyla pouze staticky umístěna na stativu, ale byla rovněž obsluhována kameramanem, podobně jako kamera snímající učitele. Pro kvalitní přenos zvukové části záznamu měl na sobě učitel umístěn bezdrátový klopový mikrofon (Janíková et al., 2008, s. 99 - 100).

Zpracování videozáznamů následně proběhlo v počítačovém programu Videograph (např. viz Janík \& Miková, 2006, s. 55), jehož prostřednictvím byly záznamy digitalizovány, pro potřeby následné analýzy transkribovány ${ }^{2}$ a dále kódovány ${ }^{3}$. Pro kódování však bylo potřeba nejprve vytvořit tzv. kategoriální systém, pomocí něhož se v předepsaných intervalech (v našem případě se jednalo o 10 sekund) rožrazovaly jednotlivé pozorované jevy do připravených skupin, neboli kategorií (ke kategoriálnímu systému viz dále). Nezbytnou pomůckou pro samotné kódování bylo i vytvoření Manuálu pro kódování DŘS, který kromě charakteristik jednotlivých kategorií obsahuje i praktické př́íklady a návody pro postup u specifických či nejasných situací.

Data, získaná uvedenou analýzou, byla následně statisticky vyhodnocena prostřednictvím relativních četností zjištěných kategorií a graficky zpracována pomocí softwaru Statistica 10.

\section{Kategoriální systém pro kódování didaktických řídicích stylů}

Průběh tvorby a výslednou podobu tohoto kategoriálního systému, včetně postupu kódování, jsme již publikovali na stránkách STUDIA SPORTIVA (č. 2, roč. 6/2012). Zde proto uvedeme pouze souhrn a hlavně úpravy a komentáře, vzniklé až po uvedené publikaci.

Podklady pro tvorbu kategoriálního systému pro kódování DŘS tvořily následující zdroje:

1) charakteristiky jednotlivých DŘS (srov. Dobrý, 2007, s. 12 - 14; Mosston \& Ashworth, 2008, s. 76 - 288),

2) návrh obsahového vymezení kategorií z období plánování jednotlivých analýz projektu videostudie TV dle Janíkové et al. (2008, s. 107 - 110),

3) kategoriální systém pro kódování DŘS dle Curtnera-Smithe (2001) „Instrument for Identifying Teaching Styles".

Výtah ze sestaveného kategoriálního systému, určeného pro potřeby našeho výzkumu, uvádí tabulka 2 (jsou zde uvedena pouze obsahová vymezení kategorií, praktické př́klady jsou z rozsahových důvodů vypuštěny). Popis pro kódování specifických situací ve výuce je uveden v tabulce 3; kurzívou je vyznačena specifická situace a pod ním je definován postup při jejím kódování. Po vytvoření byl kategoriální systém ověřen pomocí sedmi cvičných vyučovacích jednotek, kódovaných vždy dvěma kódovateli.

\footnotetext{
${ }_{3}^{2}$ Transkripce - převedení verbální komunikace do psané podoby (Janík \& Miková, 2006, s. 56).

${ }^{3}$ Kódování - systematická registrace a kategorizace jevů, pozorovaných na videozáznamu (Janík \& Miková, 2006, s. 60)
} 


\section{Tab. 2. Obsahové vymezení jednotlivých kategorii pro kódování Ď̆S}

\begin{tabular}{|c|c|}
\hline Kategorie & Obsahové vymezení \\
\hline 0: žádná & Č̌innosti před zahájením a po skončení výuky a činnosti při přerušení výuky. \\
\hline 1: př́íkazový & $\begin{array}{l}\text { Veškerá rozhodnutí činí učitel a žák na každé učitelovo rozhodnutí reaguje } \\
\text { požadovaným způsobem (učitel dává pro každý úkon řídící signál, na který žák } \\
\text { požadovaným způsobem odpovídá). Učitel především žáky instruuje, dává povely } \\
\text { a signály k zahájení, ukončení, přerušení či navázání cvičení, udává tempo cvičení, } \\
\text { určuje místo provádění, zadává pořadí jednotlivých úkolů a poskytuje zpětnou } \\
\text { vazbu o mî́re shody se stanoveným provedením úkolu (častým a typickým jevem } \\
\text { v tomto stylu je, že je-li poskytována zpětná vazba pouze jednomu nebo skupině } \\
\text { žáků, je zpravidla zastaveno i cvičení ostatních). }\end{array}$ \\
\hline 2: praktický & $\begin{array}{l}\text { Učitel činí rozhodnutí o učivu (seznamuje žáky s úkoly, které je čekají a popisuje } \\
\text { jejich provedení) a logistickém zabezpečení výuky (informuje žáky o prostorových } \\
\text { nárocích cvičení, potřebném vybavení, aktivitě při přestávce mezi cvičeními apod.). } \\
\text { Během samotného cvičení žákủ je pak jeho úkolem žáky pozorovat a poskytovat } \\
\text { jim individuální zpětnou vazbu, případně odpovídat na jejich doplňující otázky } \\
\text { ohledně cvičení. Rozhodnutí, týkající se prováděného cvičení, jsou však přenesena } \\
\text { z učitele na žáka (např. volba místa pro cvičení, volba zahájení či ukončení cvičení, } \\
\text { volba tempa či rytmu cvičení, volba pořadí dílčích úkolů atd.). }\end{array}$ \\
\hline 3: reciproční & $\begin{array}{l}\text { Učitel připravuje kritéria provedení požadovaného výkonu, podle kterých žáci } \\
\text { následně cvičí ve dvojicích, jeden v roli cvičícího, druhý v roli pozorovatele. } \\
\text { V průběhu výuky pak učitel poskytuje individuální zpětnou vazbu, ovšem pouze } \\
\text { žákovi fungujícímu v roli pozorovatele. }\end{array}$ \\
\hline 4: se sebehodnocením & $\begin{array}{l}\text { Učitel připravuje kritéria hodnocení požadovaného výkonu. Žáci cvičí a podle } \\
\text { těchto připravených kritérií provádějí sebehodnocení svého výkonu. Učitel při } \\
\text { cvičení žáky pozoruje a pomáhá jim rozvíjet jejich sebehodnotící dovednosti. }\end{array}$ \\
\hline 5: s nabídkou & $\begin{array}{l}\text { Učitel stanoví kritéria pro provedení a hodnocení výkonu a jednotlivé stupně } \\
\text { obtížnosti jeho provedení. Žáci provádí dané cvičení, přičemž sami rozhodují } \\
\text { o stupni obtížnosti. Učitel žáky při cvičení pozoruje a podporuje jejich } \\
\text { sebehodnocení. }\end{array}$ \\
\hline $\begin{array}{l}\text { 6: s řízeným } \\
\text { objevováním }\end{array}$ & $\begin{array}{l}\text { Učitel volí cílový koncept (cíl objevování), definuje otázky nebo problémy, jejichž } \\
\text { rešení povede k objevení tohoto cílového konceptu a určuje jejich sled. Žáci pak } \\
\text { v určeném pořadí hledají odpovědi na položené otázky nebo řešení předestřených } \\
\text { problémů a snaží se dosáhnout cílového konceptu. }\end{array}$ \\
\hline $\begin{array}{c}\text { 7: s přímočarým } \\
\text { objevováním }\end{array}$ & $\begin{array}{l}\text { Učitel volí cílový koncept (cíl objevování) a definuje jeden vstupní podnět, který } \\
\text { směřuje k objevení tohoto jediného cílového konceptu (otázka, problém, situace } \\
\text { apod.). Žáci objevují cílový koncept tím, že bez předchozí zkušenosti nad ním } \\
\text { uvažují, kladou si sami další otázky, hledají souvislosti a jejich posloupnost atd. }\end{array}$ \\
\hline $\begin{array}{l}\text { 8: s tvořivým } \\
\text { objevováním }\end{array}$ & $\begin{array}{l}\text { Učitel rozhoduje o tématu výuky. Definuje jeden vstupní podnět, za účelem } \\
\text { objevení více možných řešení (otázka, problém, situace apod.). Žáci pak na tento } \\
\text { podnět reagují a bez předchozí zkušenosti objevují možná řešení problému. }\end{array}$ \\
\hline $\begin{array}{l}\text { 9: s autonomním } \\
\text { rozhodováním žáka } \\
\text { o učivu }\end{array}$ & $\begin{array}{l}\text { Učitel rozhoduje pouze o tématu výuky. O způsobu provedení tohoto tématu } \\
\text { rozhodují následně žáci sami (pomocí otázek specifikují téma, identifikují postupy, } \\
\text { které povedou k řešení a určují kritéria provedení a hodnocení). Učitel řeší se žáky } \\
\text { logistické zabezpečení výuky, a pokud je požádán poskytuje pomoc či radu. }\end{array}$ \\
\hline $\begin{array}{l}\text { 10: s autonomním } \\
\text { rozhodováním žáka } \\
\text { o volbě stylu }\end{array}$ & $\begin{array}{l}\text { Téma výuky navrhují žáci a také } \mathrm{k} \text { němu činí všechna potřebná rozhodnutí. } \\
\text { Samostatně pak zahajují i proces učení. Učitel poskytuje zpětnou vazbu } \\
\text { o rozhodnutích, která v rámci procesu učení žáci učiní a podporu a všeobecnou } \\
\text { pomoc, dle jejich žádosti. }\end{array}$ \\
\hline 11: více stylů současně & $\begin{array}{l}\text { Ve stejném časovém úseku je ve výuce realizováno více stylů současně, přičemž } \\
\text { každá taková epizoda má stejnou důležitost (učitel věnuje práci všech skupin } \\
\text { přiměřenou pozornost - komunikuje s nimi, pozoruje jejich činnost atd.). }\end{array}$ \\
\hline 12: jiné & $\begin{array}{l}\text { Činnosti, které mají primárně organizační charakter (např. nástup žáků, příprava } \\
\text { nebo úklid nářadí, rozdělování žákủ do skupin, přesuny žákủ během výuky atd.), } \\
\text { nebo činnosti, vyplývající z průběhu a okolností výuky (např. zapisování výkonů } \\
\text { žáků, zkoušení nářadí učitelem, řešení kázeňských problémů žákủ atd.). }\end{array}$ \\
\hline
\end{tabular}




\section{Tab. 3. Pokyny pro kódování specifických situací}

\section{Chybí formální zahájení výuky}

Pokud na začátku vyučovací hodiny chybí formální zahájení výuky, jako je nástup nebo jiná obdobná forma, kóduje se výuka od momentu, kdy skutečně začíná probíhat, resp. od zahájení úvodního cvičení dle příslušného stylu, ve kterém je toto cvičení prováděno (např. žáci se ihned po vstupu do tělocvičny začínají na pokyn učitele: „Tak a běžíme...“ rozklusávat - od momentu, kdy žáci zareagují na pokyn k rozklusání se kóduje podle stylu, ve kterém je rozklusání vedeno), nebo od zahájení přípravy na samotnou výuku (např. žáci připravují náčiní, které bude k výuce potřeba - od momentu, kdy žáci reagují na pokyn k zahájení př́pravy se kóduje jako kategorie 12: jiné). Je-li proveden nástup nebo jiná obdobná forma zahájení dodatečně, kóduje se bez ohledu na to, že je prováděna až po skončení nějakého úvodního cvičení (tedy jako kategorii 12: jiné).

\section{Učitel se nevěnuje probíhající výuce nebo opustí místo výuky}

Pokud je výuka skutečně přerušena, tzn. že žáci přestanou cvičit, potom se kóduje jako kategorie 0: žádná. Pokud ale v této době není cvičení žáků přerušeno a žáci tak dál plní úkoly zadané učitelem, potom se kóduje podle př́slušného stylu. Dojde-li ke kombinaci těchto dvou možností, tedy např. učitel odejde z tělocvičny a žáci cvičí dál, ale cvičí to, co právě oni chtějí (jejich cvičení tedy nevyplývá ani z pokynů učitele ani z probíhající výuky), potom se kóduje stejně jako v prvním případě, a to jako kategorie 0: žádná.

\section{Přestávka na „vydýcháni"“}

Odpočinek je nedílnou součástí tělesných cvičení, proto se kóduje jako styl cvičení, se kterým je v př́mé souvislosti. Obdobně postupujeme, pokud jsou zadány pokyny typu „,vyklepte si nohy“, „protřepejte ruce“, „protáhněte se“ apod. (jedná se také o pokyny vedoucí k nějakému způsobu odpočinku v rámci cvičení). Pokud mají žáci přestávku na vydýchání, ale během toho provádějí z pověření učitele ještě nějakou jinou další činnost, kóduje se přednostně tato další prováděná činnost (např. „Tak, vydýchejte se a pojd’te zatím nachystat ty žíněnky.").

\section{Proměňování získaných trestných bodů za určitý počet cviků}

Jestliže žáci v průběhu nějakého cvičení získali určitý počet trestných bodů (napřr. za každé chycení při honičce získává žák jeden trestný bod) a po skončení daného cvičení mají tyto získané trestné body „proměnit“ za příslušný počet nějakých cviků (např. za každý trestný bod jeden dřep s výskokem), kóduje se jako kategorie podle předcházejícího cvičení. V některých př́ípadech sice může mít toto následné cvičení znaky jiného DŘS, ale protože neplní konkrétní cíle $\mathrm{v}$ dané vyučovací jednotce, zapojení žákủ je zpravidla nevyvážené (někteří necvičí vůbec, protože nezískali žádný trestný bod, jiní cvičí kratší dobu než ostatní, protože získali méně trestných bodů) a statisticky nejsou tyto úseky významné, nekódujeme je samostatně.

\section{Cvičení po skupinách}

Za cvičení po skupinách považujeme taková cvičení, při kterých žáci cvičí v jasně rozdělených a alespoň pro určité cvičení stálých skupinách o dvou a více členech (napr. cvičení na stanovištích, ve dvojicích, po družstvech atd.). Při kódování těchto cvičení je důležité rozlišovat, jsou-li všechny skupiny vedeny $\mathrm{v}$ témže stylu, nebo je-li alespoň jedna ze skupin vedena v jiném stylu než ostatní. V prvním případě se kóduje jako kategorie př́íslušného stylu, ve druhém případě se kóduje jako kategorie 11: více stylů současně.

\section{Vyřazování žáků z určitého cvičení}

Je-li realizováno cvičení, v jehož průběhu jsou někteří žáci vyřazováni (např. žáci, kteří při skoku vysokém nepřekonají určitou výšku), pak nastávají zpravidla následující možnosti.

1) Vyřazení žáci dále necvičí a pouze přihlížejí - kóduje se jako kategorie př́slušného stylu podle činnosti žáků, kteří cvičí, a to až do skončení cvičení, ačkoli se v takovém případě mohou přihlížející žáci stát většinou.

2) Vyřazení žáci dostávají určitý doplňkový úkol - zde mohou nastat opět dvě možnosti.

a) Úkol je zadán nestrukturovaně, bez konkrétních kritérií či požadavků a nelze tak jasně posoudit v jakém stylu žáci pracují (např. „Budete si házet na koš.“, „Můžete si jít kopat.“ apod.) - kóduje se jako kategorie podle činnosti žáků vykonávajících hlavní aktivitu.

b) Úkol je zadán žákům jasně, pomocí konkrétních kritérií či požadavků a lze tudíž přesně určit, v jakém stylu žáci pracují (např. „Budete procvičovat střelbu na koš z místa z hranice vyhrazeného území, dodržujete přitom veškeré zásady, které jsme si minule řekli...“, „Budete si ve dvojicích nebo trojicích procvičovat přihrávky na krátkou a střední vzdálenost se zpracováním míče a až vás bude alespoň 10 , tak se rozdělíte na dvě družstva a dáte si zápas na širrku hřiště...") - kóduje se jako cvičení ve skupinách, ačkoli skupiny v tomto případě nejsou stálé. 


\section{Žáci jsou do cvičení zapojováni nerovnoměrně}

Pokud je cvičení realizováno tím způsobem, že cvičí pouze část žáků a ostatní čekají, až se budou moct do cvičení také zapojit (např. při šplhu, několik žáků šplhá a ostatní čekají, až jim cvičící uvolní šplhadla), pak se kóduje jako kategorie ve stylu, ve kterém pracují cvičící.

\section{Dvě a více současně probíhajicích výuk v jednom cvičebním prostoru}

Probíhá-li v jednom cvičebním prostoru oddělená výuka dvou a více výukových skupin žáků, přičemž každou vede jiný vyučující, kóduje se podle činnosti učitele a žáků vybrané zájmové skupiny. Provádějí-li některá cvičení tyto skupiny společně, přičemž ji vede jen jeden z přítomných učitelů (a nemusí to být učitel kmenově př́slušný k vybrané zájmové skupině žáků), kóduje se podle činnosti většiny žáků z vybrané zájmové skupiny.

\section{Přenesení ř́dicích činností z učitele na žáka}

Jestliže učitel přenese řízení výuky (výběr cvičení, vysvětlení provedení cvičení, organizace cvičení atd.) na žáka či skupinu žáků a nadále do jeho či jejich řízení významně nezasahuje (může však vypomáhat napřr. zpřesňováním vysvětlení, doplněním bezpečnostních zásad apod.), kóduje se podle způsobu řízení tohoto žáka či žáků, nebot' v dané chvíli vlastně nahrazují učitele.

\section{Žáci se domlouvaji na taktice týmu v rámci sportovní nebo pohybové hry}

Doba domluvy se kóduje jako součást cvičení, se kterým souvisí, nebot' taktika je součástí výkonu, a proto i domluva na taktice je součástí samotného cvičení.

\section{Měreni skočené či hozené vzdálenosti}

Měření skočené (např. skok daleký) či hozené (např. hod kriketovým míčkem) vzdálenosti považujeme za součást daného cvičení (jde v podstatě o zpětnou vazbu o výkonu), proto se tato činnost kóduje jako kategorie ve stylu př́slušného cvičení.

Vedle kategorií jednotlivých DŘS se v rámci kategoriálního systému objevily i kategorie specifické, označené jako „žádná“, „více stylů současně“ a ,jiné“"

Kategorie „0: žádná“ je určena k zachycení jevů, probíhajících mimo samotnou výuku. Abychom mohli určit, které jevy probíhají v rámci výuky, a které nikoli, museli jsme nadefinovat kritéria, která budou výuku přesně vymezovat. Jako kritérium pro zahájení výuky jsme si stanovili okamžik, od kterého začíná výuka oficiálně probíhat, tedy napřr. zahájení úvodního nástupu žáků, nebo jakékoli učitelovo prohlášení výuky za zahájenou (např. „V dnešní hodině se budeme věnovat...“, nebo „Tak se utište, hodina už začala...“ atp.) nebo pokyn k zahájení prvního cvičení (např. „Rozcvičku dnes povede...“, nebo „První cvičení, které si dnes uděláme..." atp.). Za skončení výuky považujeme naopak okamžik, ve kterém byla výuka oficiálně ukončena, jako např. ukončení závěrečného nástupu žáků, nebo jakékoli učitelovo prohlášení výuky za skončenou (např. „Máte přestávku.““, nebo „To je vše, můžete odcházet.“ atp.), nebo př́padně ukončení posledního cvičení nebo činnosti s ním související (úklid nářadí, zpětná vazba apod.). Za přerušení výuky pak označujeme pouze takovou dobu, po kterou byla výuka $z$ důvodu vnějších vlivů přerušena a vůbec neprobíhala. Jako vnější vlivy chápeme takové události, které učitel nemůže svou vlastní činností ovlivnit (např. ošetřování zranění či řešení akutních zdravotních potíží žáků, náhlá změna počasí při venkovní výuce, která znemožňuje její další průběh, vyučující je nucen odejít $\mathrm{z}$ výuky atd.). Jsme si vědomi toho, že za určitých okolností mohou i jevy probíhající mimo výuku nést znaky některého z DŘS, to však nebylo předmětem uvedeného výzkumu.

Častou organizační formou práce v TV je práce skupinová (srov. Janíková, Janík \& Kamírová, 2009, s. 110 - 111). Činnosti ve skupinách dovolují učiteli např. poskytnout žákům prostor pro vícenásobné zopakování určitého cvičení nebo pro procvičení více dovedností v rámci jedné vyučovací jednotky. Také učiteli dávají více možností k individuálnímu př́istupu k žákům. Zároveň tento způsob vedení výuky učiteli umožňuje aplikovat pro práci jednotlivých skupin i různé DŘS. Protože v takovém případě vzhledem $\mathrm{k}$ integrovanému př́ínosu, komplementaritě a vzájemné nekontraverznosti jednotlivých stylů (Rychtecký \& Fialová, 1998, s. 119), nelze rozhodnout, který styl je z hlediska vyhodnocení „důležitější“ a měl by se tudíž zaznamenat, vytvořili jsme kategorii „11: více stylů současně“. Ta by byla uplatňována v těch případech, kdy by bylo ve výuce ve stejném časovém úseku realizováno prostřednictvím skupinové práce více DŘS současně (tzn. že alespoň jedna skupina by byla vedena $v$ jiném stylu než ostatní), přičemž všechny takové epizody by byly vzájemně rovnocenné (učitel věnuje práci všech skupin přiměřenou pozornost, komunikuje s nimi, pozoruje jejich činnost atd.). $Z$ této kategorizace sice nelze následně rozpoznat, jaké konkrétní DŘS byly v dané situaci realizovány, ale vzhledem 
k velkému počtu možných kombinací jednotlivých DŘS a tedy i vzhledem k velkému počtu potencionálních kategorií, které by tyto konkrétní kombinace zachycovaly, jsme se rozhodli využít kategorii „univerzální“. Př́ípadné konkrétní kombinace DŘS je ovšem pochopitelně možné poznamenat a poté uvést např. při prezentaci či interpretaci výsledků.

Podle Tomajka a Dobrého se učitel v každém okamžiku své vyučovací činnosti nachází v jednom z dosud známých DŘS (2002, s. 30). Součástí těchto vyučovacích činností učitele jsou i činnosti organizační (srov. Vilímová, 2002, s. 59). Mezi takové činnosti bychom mohli zařadit napřr. přípravu nebo úklid nářadí, rozdělování žáků do skupin, přesuny žáků během výuky atp. Na základě výše uvedeného, je i u těchto specificky organizačních činností možné určovat použité DŘS. V našem výzkumu jsme však pro tento druh činností vytvořili samostatnou kategorii „12: jiné“ (viz výše uvedený kategoriální systém), k čemuž nás vedly dvě skutečnosti.

1. Činnosti primárně organizačního charakteru (např. přesuny žáků, rozdělování žáků do skupin apod.) slouží především k zajištění průběhu vyučovací jednotky. Způsob provedení těchto činností souvisí s úrovní kázně žáků, pracovním ruchem, pracovním klimatem a pořádkem ve výuce (srov. Vilímová, 2002, s. 59; Rychtecký \& Fialová, 2004, s. 110). Uvědomujeme si tedy, že u nich lze rovněž identifikovat znaky DŘS, ale současně v tomto př́ípadě upřednostňujeme význam realizace DŘS v samotné učební činnosti žáků.

2. Zkušenosti z praxe a z kódování vyučovacích jednotek TV nám navíc ukázaly, že určení konkrétního DŘS je u některých činností přinejmenším problematické. Jedná se bud' o specifické činnosti v př́mé interakci učitel - žák (napřs. slovní rekapitulace či shrnutí probraného učiva, zjišt'ování a př́ípadně zapisování výkonů, kterých žáci dosáhli, vydávání náčiní), nebo o činnosti, při kterých je tato interakce dokonce bezprostředně přerušena (např. kontrola a zkoušení nachystaného nářadí učitelem, chystání pomůcek pro cvičení učitelem). Zavedení této kategorie do kategoriálního systému tedy není důsledkem nepochopení či ignorování možností výskytu činností realizovaných některým z DŘS, je dáno pouze snahou zvýraznit z našeho pohledu důležitá data. Navíc ze statistického hlediska získáváme díky této kategorizaci informace nejen o využívání DŘS, ale rovněž o časovém objemu, který připadá na organizování a zajišt’ování průběhu výuky (a ve kterém tedy žáci necvičí).

Podobný př́istup pak ve svém kategoriálním systému pro kódování DŘS zvolil už Curtner-Smith (2001). I v tomto materiálu, nazvaném „Instrument for Identifying Teaching Styles“ (dále jen „IFITS“), se kromě osmi kategorií náležejících konkrétním DŘS, nachází i kategorie „Management“ (v překladu tedy řízení, vedení). Ta je zde charakterizována jako doba, kdy se učitel zabývá činnostmi, které přmo nesouvisejí s výukou. Zahrnuje čas na začátku a na konci vyučování, na obsluhu vybavení, organizováni, re rěení chováni žákủ a jakékoli jiné úkoly ně̌ ty, sloužici $k$ vyučování nebo řizení tř́dy. Příklad: učitel vydává plováky žákiom, účastnícím se plaveckého výcviku (Curtner-Smith, 2001, s. 4).

Tento kategoriální systém Curtnera-Smithe byl následně použit ve výzkumech identifikujících využívání DŘS na stř̌edních školách v jihovýchodní Anglii (Curtner-Smith, Todorovich, McCaughtry, \& Lacon, 2001) a jihozápadní Anglii (Curtner-Smith, Hasty, \& Kerr, 2001) a sice v souvislosti s revizí kurikulárního dokumentu v oblasti TV „National Curriculum for Physical Education“. Dále jej ke splnění částí výzkumného záměru použili autoři Bryant a Curtner-Smith při výzkumu vlivu zdravotního postižení učitele TV na vnímání a učení jeho žáků na základních a středních školách na jihovýchodě USA (2008, 2009a, 2009b). A ve své práci jej použili i autoři Parker a Curtner-Smith (2012), kteří jeho prostřednictvím zkoumali vliv vzdělávání budoucích učitelů na jejich dovednost využívat DǨS během jejich studentských praxí.

\section{VÝSLEDKY ANALÝZY}

Cílem analýzy využívání DŘS ve výuce na 2 . stupni ZŠ bylo nalezení odpovědí na tři výše uvedené výzkumné otázky: Jak široké spektrum DŘS je využíváno ve výuce TV na 2. stupni ZŠs Jaké DŘS jsou ve výuce využívány nejčastěji? Liší se složení využívaného spektra DŘS s ohledem na délku praxe učitele, pohlaví učitele, pohlaví žáků nebo velikost školy? Výsledky analýzy ukázaly, že ve vyučovacích jednotkách zahrnutých do našeho výzkumu, byly využívány pouze dva DŘS - styl př́kazový a styl praktický z reprodukční části spektra DŘS. Mírnou převahu ve využívání má z těchto dvou DŘS praktický (při přepočtu procentuálního podílu pouze na kategorie DŘS se jedná o rozdíl 14,74 \%). Rozhodně nezanedbatelnými kategoriemi ve výsledcích naší analýzy jsou dále kategorie „0: žádná“ a „12: jiné“, které mají dohromady podíl 25,84 \% a tvoří tedy $1 / 4$ výsledného celku. Grafickou podobu uváděných výsledků přináší obrázek 2. 


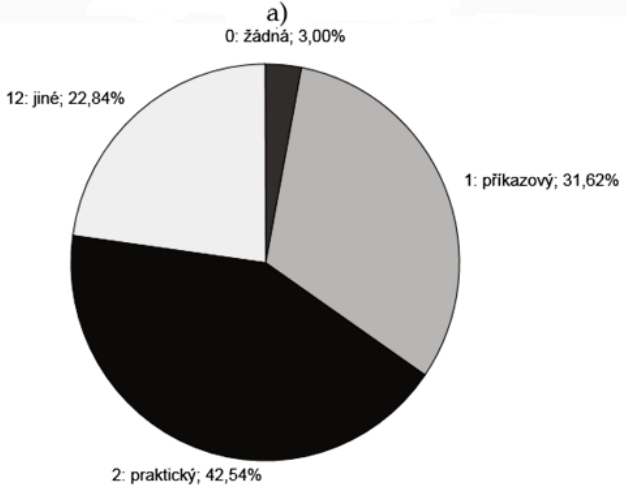

b)

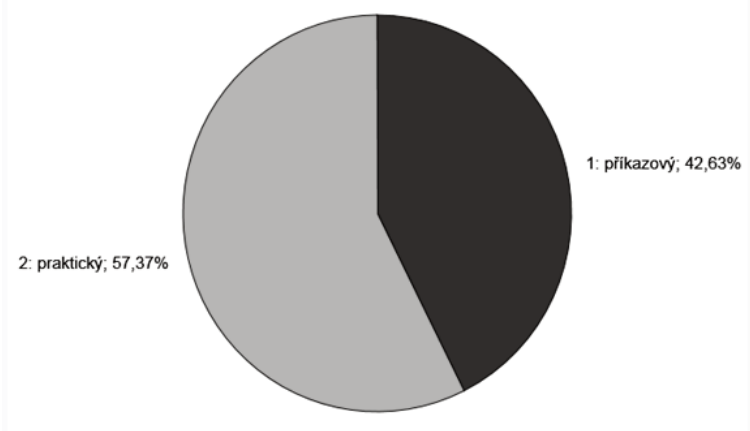

Obr. 2. Výsledky analýzy využití Ď̌S ve výuce TV na 2. stupni $Z \check{S}$

a) celkový procentuální podíl všech zjištěných kategorií

b) celkový procentuální podíl přepočítaný pouze na kategorie obou zaznamenaných DŘS

V rámci analýzy zjištěných výsledků porovnáme nyní tyto výsledky z několika různých úhlů pohledu. Obrázek 3 ukazuje podíl jednotlivých zjištěných kategorií u vyučujících rozdělených podle délky jejich praxe a obrázek 4 u vyučujících rozdělených podle pohlaví. Délku praxe považujeme za velice zajímavé hledisko z toho důvodu, že porovnání může ukázat, jestli se při využívání DŘS nějakým způsobem projevuje narůstající profesní zkušenost a možnost dalšího vzdělávání. Porovnání z pohledu pohlaví učitelů zase může identifikovat rozdíly mezi př́istupem k využívání DŘS u mužů a žen.

Výsledky porovnání podle délky praxe vykazují výraznější odlišnost u skupiny učitelů s 5 - 10 lety praxe. Zde je procentuální podíl kategorie „1: příkazový“ vzhledem k průměru zbývajících třech skupin o 15,88 \% větší, zatímco u kategorie „2: praktický“ o 10,78 \% menší. Menší odlišnost je pak patrná ještě u učitelů nad 20 let praxe, u kterých je kategorie „1: př́kazový“ o 4,99 \% větší, než u učitelů s 11 - 20 lety praxe a kategorie „2: praktický“ je o 7,48 \% menší, než u učitelů s $0-4$ lety praxe. Právě skupiny učitelů s $0-4$ lety praxe a 11 - 20 lety praxe pak vykazují v kategoriích stylů velice podobné hodnoty. Nejmenší podíl kategorie „12: jinéc mají skupiny učitelů s $0-4$ lety praxe a s $5-10$ lety praxe, největší potom skupiny učitelů s $11-20$ lety praxe a nad 20 let praxe, ovšem v průměru se jedná pouze o rozdíl 4,42 \%. Rozdíly celkového procentuálního podílu kategorií a procentuálního podílu u jednotlivých skupin učitelů podle délky praxe shrnuje tabulka 4 .

Při porovnání učitelů podle pohlaví byl u žen zjištěn nepatrně vyšší podíl kategorie „1: př́kazový“ (o 5,76 \%), zatímco u mužů byl naopak zjištěn vyšší podíl kategorie „2: praktický“ (o 4,7 \%). Zbývající dvě kategorie vykazují téměř shodné výsledky. Rozdíly celkového procentuálního podílu kategorií a procentuálního podílu u skupin mužů a žen shrnuje tabulka 4 . 
a)

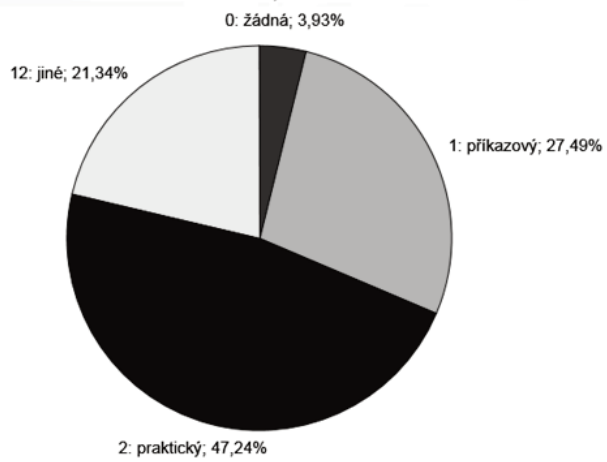

c)

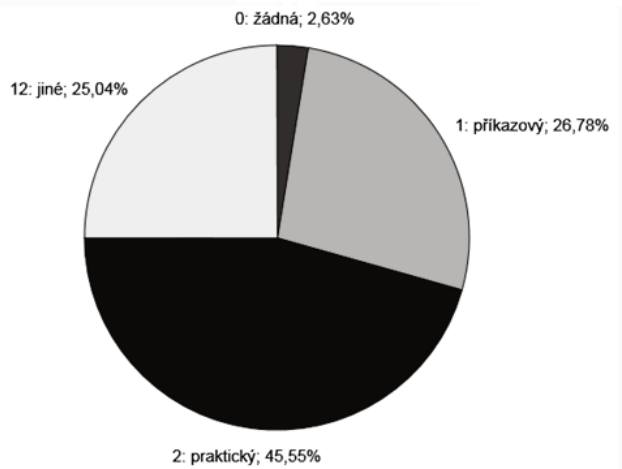

b)

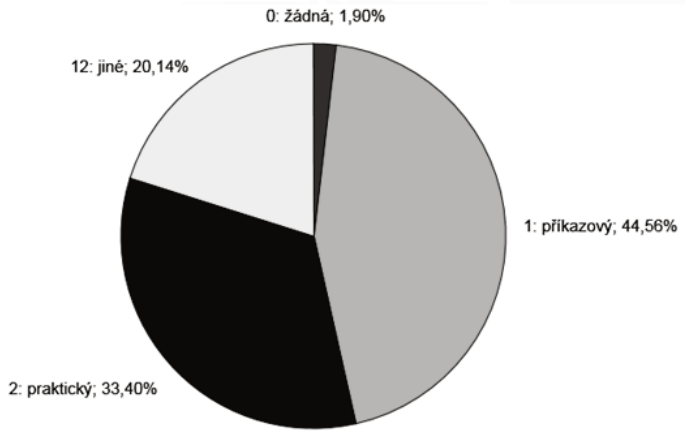

d)

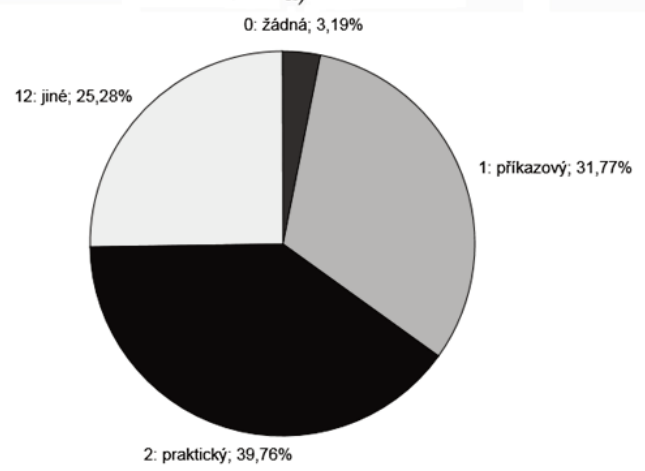

Obr. 3. Porovnáni procentuálního podílu kategorii podle délky praxe učitele

a) učitelé s $0-4$ lety praxe $(n=6$; učitelé $E, H, I, K, M, R)$

b) učitelé s $5-10$ lety praxe $(\mathrm{n}=4$; učitelé $\mathrm{B}, \mathrm{L}, \mathrm{P}, \mathrm{S})$

c) učitelé s $11-20$ lety praxe $(\mathrm{n}=6$; učitelé $\mathrm{D}, \mathrm{F}, \mathrm{J}, \mathrm{N}, \mathrm{O}, \mathrm{T})$

d) učitelé nad 20 let praxe $(\mathrm{n}=4$; učitelé $\mathrm{A}, \mathrm{C}, \mathrm{G}, \mathrm{Q})$

a)

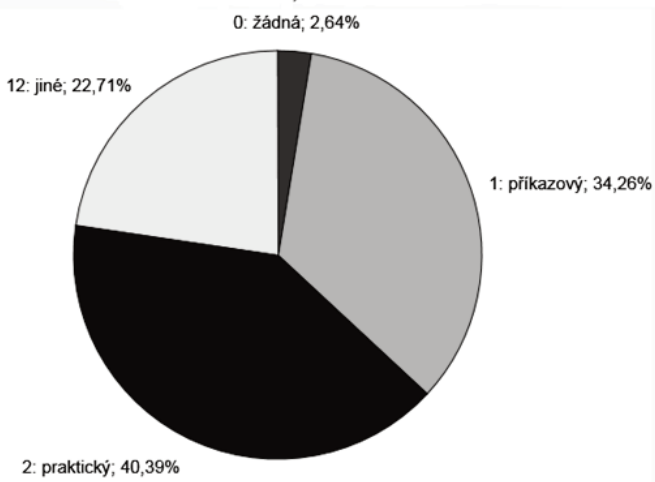

b)

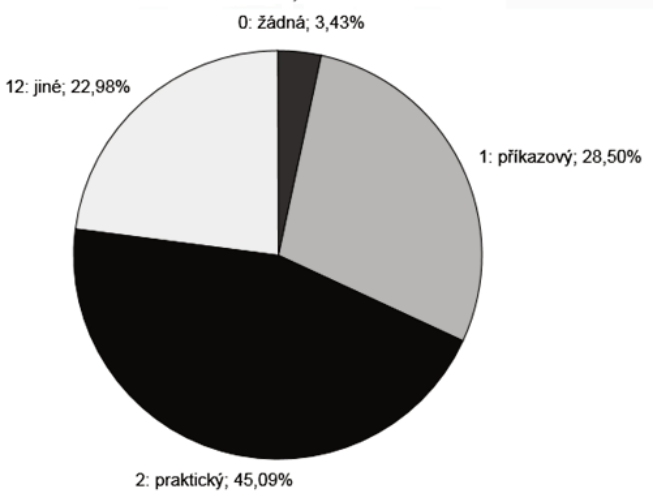

Obr. 4. Porovnání procentuálního podílu kategorií podle pohlaví učitelì

a) Ženy ( $\mathrm{n}=10$; učitelé $\mathrm{A}, \mathrm{B}, \mathrm{C}, \mathrm{D}, \mathrm{J}, \mathrm{K}, \mathrm{L}, \mathrm{M}, \mathrm{N}, \mathrm{R})$

b) muži $(\mathrm{n}=10$; učitelé E, F, G, H, I, O, P, Q, S, T)

Přístup učitele $\mathrm{k}$ realizaci jednotlivých DŘS je nepochybně ovlivněn i kázní a př́istupem žáků k výuce a samozřejmě také obsahem vyučovací jednotky. Proto uvádíme i porovnání podílu jednotlivých kategorií podle pohlaví žáků, kteří se vyučovací jednotky účastnili. Vyučovací jednotky dívek a chlapců totiž mají zpravidla nejen rozdílné fyzické nároky, ale odlišují se často i po stránce obsahové (preference aktivit, napřr. fotbal vs. volejbal, sportovní vs. moderní gymnastika atd.). Procentuální podíl zastoupení jednotlivých kategorií u dívek a chlapců přináší obrázek 5 . Z grafů je patrné, že u vyučovacích jednotek chlapců má o 4,66 \% vyšší 
podíl kategorie „1: prríkazový“, zatímco kategorie „2: praktický“ je u chlapců oproti dívkám o 6,39 \% nižší. Kategorie „12: jiné“ se liší pouze nepatrně, u chlapců je o 1,45 \% vyšší. Rozdíly celkového procentuálního podílu kategorií a procentuálního podílu u skupin vyučovacích jednotek dívek a chlapců shrnuje tabulka 4.

a)

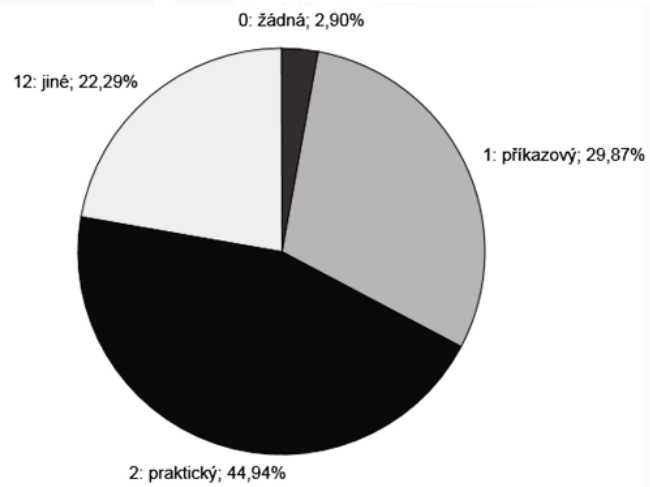

b)

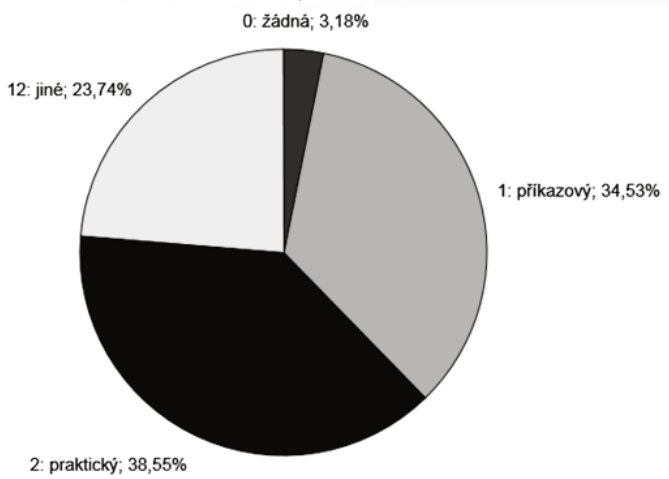

Obr. 5. Porovnání procentuálního podílu kategorii podle vyučovacích jednotek dívek a chlapců

a) dívky $(\mathrm{n}=35)$

b) $\operatorname{chlapci}(\mathrm{n}=23)$

Z pohledu využivání DŘS ve výuce TV považujeme za zajímavé i porovnání výsledků z hlediska velikosti škol, na kterých byly vyučovací jednotky pořízeny. Toto porovnání totiž v první řadě potencionálně odráží možnosti materiálního zabezpečení výuky TV (větší školy zpravidla disponují i většími možnostmi). Ty pochopitelně do jisté míry ovlivňují obsahovou náplň výuky (kvalitou a kvantitou pomůcek, velikostí tělocvičny, možností využívat venkovní hřiště atd.), a tím i realizaci DŘS. Zajímavým faktorem z hlediska velikosti škol je i možnost různé organizace výuky ( 2 x týdně 1 hodina TV, 1 x týdně 2 hodiny TV), která se do jisté míry může rovněž promítnout do využití DŘS. V našem výzkumu bylo sice zaznamenáno pouze 7 př́padů organizace $1 \mathrm{x}$ týdně 2 hodiny TV, ale ve všech př́padech se jednalo o školy s počtem žáků nad 450 . Výsledek tohoto porovnání ukazuje obrázek 6. 
a)

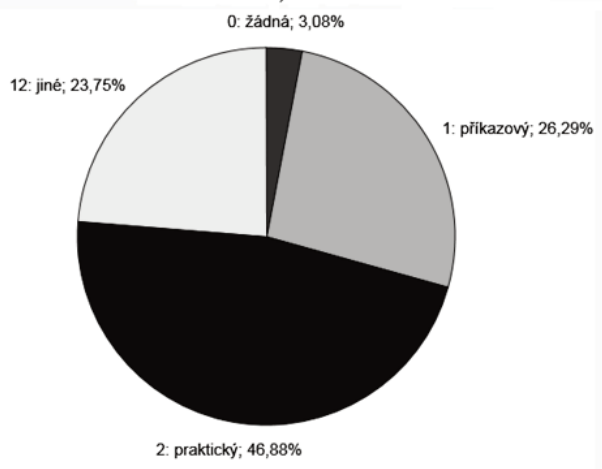

c)

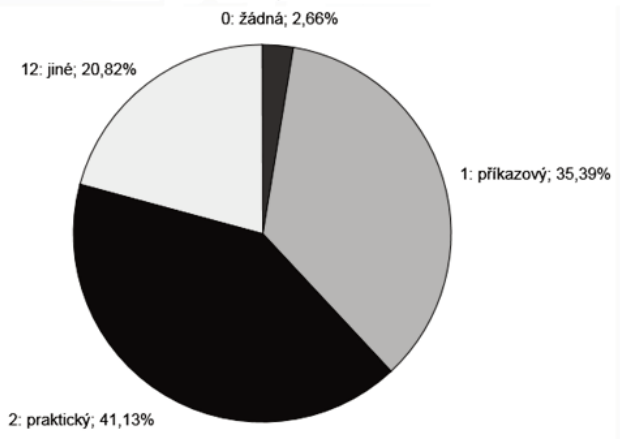

b)

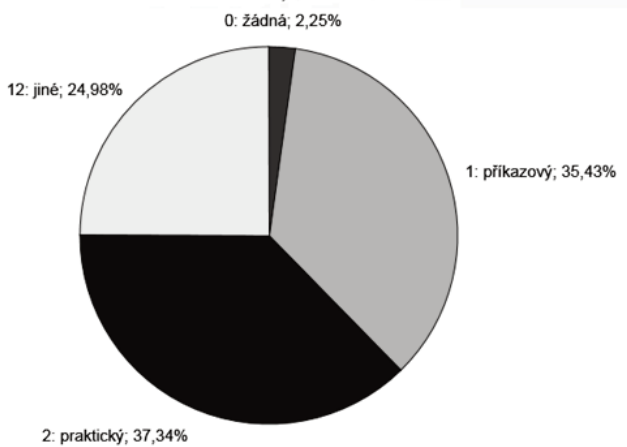

d)

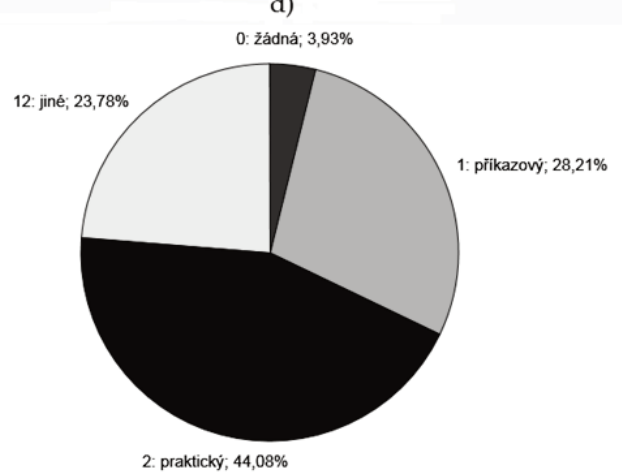

Obr. 6. Porovnání procentuálního podílu kategorii podle počtu žáki̊ školy

a) školy do 200 žáků $(\mathrm{n}=4$; př́íslušní učitelé $\mathrm{C}, \mathrm{D}, \mathrm{F}, \mathrm{P})$

b) školy od 201 do 400 žáků $(n=4$; příslušní učitelé $G, K, L, Q)$

c) školy od 401 do 600 žáků ( $n=7$; příslušní učitelé $B, H, J, M, R, S, T)$

d) školy nad 600 žáků ( $n=5$; příslušní učitelé $A, E, I, N, O)$

Školy s 201 - 400 žáky a školy s 401 - 600 žáky mají větší podíl kategorie „1: příkazový“ (mezi skupinou škol s 201 - 400 žáky a skupinou škol do 200 žáků je rozdíl 9,14%). Podíl kategorie ,2: praktický“ v jednotlivých skupinách relativně rovnoměrně stoupá od hodnoty $37,34 \%$ po $46,88 \%$, přičemž nejnižší podíl má skupina škol s 201 - 400 žáky, o 3,79 \% více má následně skupina škol s 401 - 600 žáky, o dalších 2,95 \% více má skupina škol nad 600 žáků a nejvyšší zastoupení (o 2,8 \% více než předchozí skupina) má skupina škol do 200 žáků. Kategorie „12: jiné“ je u skupin škol do 200 žáků, s 201 - 400 žáky a nad 600 žáků zastoupena velice blízkými hodnotami, jejichž průměr se rovná 24,17 \%. U skupiny škol s 401 - 600 žáky je podíl jejího zastoupení o 3,35 \% nižší. Rozdíly celkového procentuálního podílu kategorií a procentuálního podílu kategorií podle počtu žáků školy shrnuje tabulka 4. 
Tab. 4. Porovnání rozdílů mezi celkovým procentuálním podílem jednotlivých kategorií a procentuálními podíly kategorií v rámci dílčich porovnání

\begin{tabular}{|c|c|c|c|c|c|c|c|}
\hline $\begin{array}{c}\text { Skupina } \\
\text { porovnávání }\end{array}$ & $\begin{array}{c}\text { Podíl } \\
(\%)\end{array}$ & $\begin{array}{c}\text { Celkový } \\
\text { podíl } \\
(\%)\end{array}$ & $\begin{array}{c}\text { Rozdíl } \\
(\%)\end{array}$ & $\begin{array}{c}\text { Skupina } \\
\text { porovnávání }\end{array}$ & $\begin{array}{l}\text { Podíl } \\
(\%)\end{array}$ & $\begin{array}{c}\text { Celkový } \\
\text { podíl } \\
(\%)\end{array}$ & $\begin{array}{c}\text { Rozdíl } \\
(\%)\end{array}$ \\
\hline \multicolumn{4}{|c|}{ Porovnání dle délky praxe učitele } & \multicolumn{4}{|c|}{$\begin{array}{c}\text { Porovnání dle vyučovacích jednotek dívek } \\
\text { a chlapců }\end{array}$} \\
\hline $0-4$ roky praxe & & & & Divky & & & \\
\hline 1: př́kazový & 27,49 & 31,62 & $-4,13$ & 1: př́íkazový & 29,87 & 31,62 & $-1,75$ \\
\hline 2: praktický & 47,24 & 42,54 & 4,70 & 2: praktický & 44,94 & 42,54 & 2,4 \\
\hline 12: jiné & 21,34 & 22,84 & $-1,50$ & 12: jiné & 22,29 & 22,84 & $-0,55$ \\
\hline $5-10$ let praxe & & & & Chlapci & & & \\
\hline 1: př́́kazový & 44,56 & 31,62 & 12,94 & 1: př́íkazový & 34,53 & 31,62 & 2,91 \\
\hline 2: praktický & 33,40 & 42,54 & $-9,14$ & 2: praktický & 38,55 & 42,54 & $-3,99$ \\
\hline 12: jiné & 20,14 & 22,84 & $-2,7$ & 12: jiné & 23,74 & 22,84 & 0,9 \\
\hline $11-20$ let praxe & & & & \multicolumn{4}{|c|}{ Porovnání dle počtu žáků školy } \\
\hline 1: př́íkazový & 26,78 & 31,62 & $-4,84$ & Do 200 žáků & & & \\
\hline 2: praktický & 45,55 & 42,54 & 3,01 & 1: př́íkazový & 26,29 & 31,62 & $-5,33$ \\
\hline 12: jiné & 25,04 & 22,84 & 2,2 & 2: praktický & 46,88 & 42,54 & 4,34 \\
\hline Nad 20 let praxe & & & & 12: jiné & 23,75 & 22,84 & 0,91 \\
\hline 1: př́íkazový & 31,77 & 31,62 & 0,15 & Od 201 do 400 žáků & & & \\
\hline 2: praktický & 39,76 & 42,54 & $-2,78$ & 1: př́íkazový & 35,43 & 31,62 & 3,81 \\
\hline \multirow[t]{2}{*}{ 12: jiné } & 25,28 & 22,84 & 2,44 & 2: praktický & 37,34 & 42,54 & $-5,2$ \\
\hline & \multicolumn{3}{|c|}{ Porovnání dle pohlaví učitelů } & 12: jiné & 24,98 & 22,84 & 2,14 \\
\hline Ženy & & & & Od 401 do 600 žáků & & & \\
\hline 1: př́kazový & 34,26 & 31,62 & 2,64 & 1: př́íkazový & 35,39 & 31,62 & 3,77 \\
\hline 2: praktický & 40,39 & 42,54 & $-2,15$ & 2: praktický & 41,13 & 42,54 & $-1,41$ \\
\hline 12: jiné & 22,71 & 22,84 & $-0,13$ & 12: jiné & 20,82 & 22,84 & $-2,02$ \\
\hline Muži & & & & Nad 600 žáků & & & \\
\hline 1: prúḱkazový & 28,50 & 31,62 & $-3,12$ & 1: př́íkazový & 28,21 & 31,62 & $-3,41$ \\
\hline 2: praktický & 45,09 & 42,54 & 2,55 & 2: praktický & 44,08 & 42,54 & 1,54 \\
\hline 12: jiné & 22,98 & 22,84 & 0,14 & 12: jiné & 23,78 & 22,84 & 0,94 \\
\hline \multicolumn{8}{|c|}{$\begin{array}{l}\text { Vysvětlivky: } \\
\text { 1) Kladná hodnota ve sloupci „Rozdíl (\%)“ znamená, že podíl ve skupině porovnání je větší než podíl } \\
\text { celkový. } \\
\text { 2) Záporná hodnota ve sloupci „Rozdíl (\%)“ znamená, že podíl ve skupině porovnání je menší než podíl } \\
\text { celkový. }\end{array}$} \\
\hline
\end{tabular}

\section{DISKUSE}

Na základě analýzy jsme v pořízených vyučovacích jednotkách TV identifikovali použití pouze dvou DŘS z reprodukční části spektra - styl př́íkazový a styl praktický. Př́́kazový styl je prvním stylem spektra, ve kterém veškerá rozhodnutí činí učitel, styl je charakteristický jeho dominantním postavením. Praktický styl je druhým stylem spektra $\mathrm{v}$ pořadí a i zde v rozhodování stále převažuje učitelova dominance, ačkoli některá dílčí rozhodnutí jsou již přenesena na žáka (rozhodnutí o prováděném cvičení - např. volba místa, volba zahájení a ukončení cvičení, volba tempa a rytmu cvičení atd.). Z těchto výsledků tedy vyplývá, že výuka v předmětných vyučovacích jednotkách byla vedena převážně direktivním způsobem, ve kterém má dominantní roli učitel a žák činí pouze některá dílčí rozhodnutí.

Při hodnocení výsledků je ovšem nutné brát v potaz již v úvodu zmiňovaný fakt, že každý styl je jedinečný tím, jaké cíle je schopen naplňovat. Nebo-li, jak uvádí Mosston a Ashworthová, každý mezní styl je definován rozhodnutími, které ze své podstaty určují specifické výukové cíle (2008, s. 20). Je tedy zřejmé, že každý DŘS má své odůvodněné uplatnění a tedy i zařazení příkazového a praktického stylu je za př́slušných podmínek vhodné. Bez podrobného rozboru výukových cílů konkrétní vyučovací jednotky, bez znalosti stupně rozvoje pohybových dovedností žáků nebo kvality a kvantity materiálního vybavení pro výuku a dalších podmínek nelze objektivně zhodnotit míru vhodnosti zařazení konkrétního DŘS, respektive nelze konstatovat, zda by v dané 
situaci nebylo vhodnější použít jiný DŘS. Rovněž nemůžeme na základě výsledků výzkumu jednoznačně konstatovat, že v hodinách TV se (u zkoumaných učitelů) využívají pouze uvedené dva DŘS.

Jako příspěvek do diskuse považujeme za vhodné uvést výsledky i některých světových studií, které se rovněž zabývaly zjišt’ováním využívání DŘS ve výuce TV. Vzhledem k různým podmínkám uvedených výzkumů není naším cílem jejich faktografické porovnání, chceme pouze ukázat, jaký je stav řešené problematiky ve světě. Jeden z nejrozsáhlejších výzkumů v oblasti využivání DŘS v doslova celosvětovém měřítku provedla Cothranová et al. (2005). Ta do svého výzkumu zapojila celkem 1436 učitelů TV ze sedmi zemí světa (USA, Korejská republika, Austrálie, Francie, Anglie, Portugalsko, Kanada). Výsledky, zprůměrované mezi jednotlivými zeměmi, ukázaly, že nejvyužívanějším DŘS se stal styl praktický, který ve své výuce využívalo 88,5 \% učitelů, na druhém místě se umístil styl př́kazový, využívaný $82 \%$ učitelů. Tyto výsledky Cothranové et al. jsou blízké výsledkům našeho výzkumu s tím rozdílem, že učitelé v tomto výzkumu využívají ještě další DŘS. Třetím v pořadí byl styl reciproční $(75,8 \%)$, následovaly styly s nabídkou (74, 8 \%) a s řízeným objevováním $(71,7$ \%) (Cothranová et al., 2005, s. 197). Výsledky tohoto výzkumu zahrnují DŘS z celé šíře spektra. Vzhledem k rozsahu výzkumu je ovšem zřejmé, že nemohl být realizován metodou pozorování, nýbrž prostřednictvím dotazníků, které učitelé vyplňovali na základě dodaných instrukcí.

Z hlediska podobného výzkumného designu jsou tak zajímavější výsledky výzkumů, na kterých se podílel tvůrce kategoriálního systému IFITS Curtner-Smith. První z nich zkoumal využívání DŘS na středních školách v jihozápadní Anglii (Curtner-Smith, Hasty, \& Kerr, 2001). Účastnilo se jej 16 učitelů z pěti škol, přičemž na video byly zaznamenány dvě vyučovací jednotky od každého z nich, které byly následně kódovány za využití uvedeného kategoriálního systému. Druhý výzkum se zaměřil na zkoumání využívání DŘS na středních školách v jihovýchodní Anglii (Curtner-Smith, Todorovich, McCaughtry, \& Lacon, 2001). Účastnilo se ho 18 učitelů ze sedmi škol, přičemž nahrávány byly opět dvě vyučovací jednotky od každého učitele. Ty byly potom rovněž kódovány pomocí kategoriálního systému IFITS. Poslední prací pro srovnání je výzkum, zkoumající vliv vzdělávání budoucích učitelů na jejich dovednost využívat DŘS během jejich studentských praxí (Parker \& Curtner-Smith, 2012). Zapojili se do něho 2 studenti učitelství z jihovýchodu USA, kteří byli ve využívání DŘS nejprve patřičně vyškoleni. Následně vedli 20 vyučovacích jednotek na 2. stupni základní školy, přičemž tyto jednotky byly zaznamenány a následně kódovány pomocí IFITS. Prvních 10 vyučovacích jednotek bylo obsahově zaměřeno na fotbalová průpravná cvičení a hry, druhých 10 na fotbal jako sportovní hru. Výsledky uvedených zahraničních výzkumů a výzkumu našeho shrnuje tabulka 5.

Tab. 5. Výsledky vybraných zahraničních výzkumů a výsledky našeho výzkumu

\begin{tabular}{|c|c|c|c|c|c|}
\hline \multirow[t]{2}{*}{ teng } & \multirow{2}{*}{$\begin{array}{c}\text { Curtner- } \\
\text { Smith, } \\
\text { Hasty, \& Kerr } \\
(2001, \text { s. 338) }\end{array}$} & \multirow{2}{*}{$\begin{array}{l}\text { Curtner- } \\
\text { Smith, } \\
\text { Todorovich, } \\
\text { McCaughtry, } \\
\text { \& Lacon } \\
\text { (2001, s. 185) }\end{array}$} & \multicolumn{2}{|c|}{$\begin{array}{c}\text { Parker \& Curtner-Smith (2012, } \\
\text { s. 138) }\end{array}$} & \multirow{2}{*}{$\begin{array}{c}\text { Sliacky \& } \\
\text { Janíková } \\
\text { (2012) }\end{array}$} \\
\hline & & & $\begin{array}{c}\text { Fotbalová } \\
\text { průpravná } \\
\text { cvičení a hry }\end{array}$ & $\begin{array}{l}\text { Fotbal jako } \\
\text { sportovní hra }\end{array}$ & \\
\hline Styl příkazový & $6,50 \%$ & $4,28 \%$ & $2,18 \%$ & $1,00 \%$ & $31,62 \%$ \\
\hline Styl praktický & $49,65 \%$ & $72,94 \%$ & $76,77 \%$ & $64,82 \%$ & $42,54 \%$ \\
\hline Styl reciproční & $2,31 \%$ & $0,64 \%$ & $0,73 \%$ & $3,70 \%$ & $0,00 \%$ \\
\hline $\begin{array}{l}\text { Styl se } \\
\text { sebehodnocením }\end{array}$ & $0,90 \%$ & $0,39 \%$ & $0,00 \%$ & $0,00 \%$ & $0,00 \%$ \\
\hline Styl s nabídkou & $1,31 \%$ & $0,06 \%$ & $0,00 \%$ & $0,00 \%$ & $0,00 \%$ \\
\hline $\begin{array}{l}\text { Styl s šízeným } \\
\text { objevováním }\end{array}$ & $5,47 \%$ & $4,01 \%$ & $2,68 \%$ & $4,42 \%$ & $0,00 \%$ \\
\hline $\begin{array}{l}\text { Styl se } \\
\text { samostatným } \\
\text { objevováním }\end{array}$ & $3,34 \%$ & $0,98 \%$ & $0,64 \%$ & $1,02 \%$ & $0,00 \%$ \\
\hline $\begin{array}{l}\text { Styl } \\
\text { s rozhodováním } \\
\text { žáka o učivu }\end{array}$ & $0,00 \%$ & $0,00 \%$ & $0,09 \%$ & $0,09 \%$ & $0,00 \%$ \\
\hline $\begin{array}{l}\text { Ř́zízení } \\
\text { (̌́ádná+jiné) }\end{array}$ & $29,97 \%$ & $16,82 \%$ & $16,91 \%$ & $24,95 \%$ & $25,84 \%$ \\
\hline
\end{tabular}


Výsledky všech uvedených výzkumů mají na prvním místě v pořadí procentuálního podílu využívání DŘS shodnou kategorii. S výraznou převahou je to styl praktický, jehož podíl se pohybuje v poměrně širokém rozmezí 42,54 \% - 76,77 \%, přičemž právě spodní hranice je výsledkem našeho výzkumu. Druhým nejpoužívanějším DŘS je kromě výzkumu Parkera a Curtnera-Smithe (2012) styl př́kazový, jehož využitelnost se pohybuje od 4,28 \% do 31,62 \%. Uvedená horní mez u této kategorie je z našeho výzkumu a její dominance je dána tím, že kromě kategorie „0: žádná“ a „12: jiné“ již nejsou, na rozdíl od zbývajících výzkumů, jiné kategorie obsazeny. Druhým nejpoužívanějším DŘS ve výzkumu Parkera a Curtnera-Smithe (2012) se stal styl s ř́zeným objevováním, který dosáhl podílu 2,68 \% a 4,42 \%. Mezi tři nejpoužívanější DŘS v uvedených výzkumech se zařadily styly praktický, př́kazový a s řízeným objevováním (ten však není ve výsledcích našeho výzkumu). S významnějším podílem se pak ještě ve výsledcích některých výzkumů (opět kromě našeho) objevují styly reciproční a se samostatným objevováním. Zajímavé je i porovnání kategorie „کrízení“ (v našem př́ípadě „0: žádná““ a „12: jiné“), které ukazuje, že učitelé tráví organizačními činnostmi ve výuce dosti značnou část celkového času. Kromě našeho výzkumu se ve všech případech jednalo o kategorii s druhým největším procentuálním podílem.

Uvedené zahraniční výsledky ukazují, že se z pohledu identifikovaných DŘS v zásadě neliší od výsledků našeho výzkumu. Rozdíl je patrný až v zastoupení některých dalších DŘS, a to hlavně s nepřehlédnutelným podílem stylů z produkční části spektra. Vezmeme-li v potaz skutečnost, že výzkumný vzorek byl u všech ostatních uvedených výzkumů menší než v našem případě, je to nepochybně další důvod k zamyšlení.

Jsme si samozřejmě vědomi toho, že spektrum DŘS je pouze jednou z didaktických složek, která ovlivňuje kvalitu a efektivitu vyučovacího procesu TV. Protože se ale právě kvalita výuky stala v poslední době často diskutovaným tématem, považujeme za přirozené věnovat patřičnou výzkumnou pozornost všem složkám, které ji mohou ovlivňovat. Vlček a Mužík v jedné ze svých studií konstatují, že současná „tělesná výchova nemá na pohybový režim žáků průkazný vliv“ (2012, s. 30). Dotázaní bývalí absolventi ZŠ ,,měli dle získaných výsledků zřetelně kladný vztah k různým pohybovým aktivitám, ale méně vstřícný vztah k tělesné výchově“ (Vlček \& Mužík, 2012, s. 30). Podle Herciga můžeme důvody takového poklesu významu a přitažlivosti TV hledat především v práci učitele, který bud' setrvává u přežitého způsobu výuky, at' už obsahem či způsobem interakce, nebo rezignuje na výchovné a vzdělávací cíle (1994, s. 2 - 3). Přitom vyučovací činnost učitele lze podle Dobrého proměňovat právě príjetím a realizací spektra DŘS (2007, s. 8), nebot' kvalita a efektivita jeho činnosti, a tedy i výsledků žáka, závisí právě na šiři možností pro výběr (2007, s. 15). Toto tvrzení pak můžeme dále podložit konstatováním Rychteckého a Fialové, kteři uvádějí, že vhodná aplikace spektra DŘS ve výuce přináší zpestř̌ení interakcí ve školní tělesné výchově a může tak zkvalitnit její výsledky (2004, s. 122).

\section{ZÁVĚRY}

Bez znalosti dalších faktorů (jako např. cíle výuky, stupeň motorického rozvoje žáků atd.) nelze jednoznačně konstatovat, že učitelé TV na 2. stupni ZŠ nevyužívají jiné DŘS než zjištěný styl př́íkazový a praktický. Vzhledem k celkovému počtu analyzovaných vyučovacích jednotek, vzhledem k počtu jednotek každého vyučujícího (od 65 \% učitelů byly k dispozici 3 nebo 4 vyučovací jednotky), ke složení výzkumného vzorku (různá délka profesní praxe učitelů, různá velikost škol, různý regionální původ) a vzhledem k různému obsahu výuky jednotlivých zaznamenaných vyučovacích jednotek se lze domnívat, že direktivní způsob vedení výuky s dominantním postavením učitele je v současné TV na 2. stupni ZŠ výrazně zastoupen. Tento stav nekoresponduje se současnými cíli TV, které mimo jiné požadují, aby žák samostatně aktivně vstupoval do organizace svého pohybového režimu, uměl zvolit vhodný rozvojový program, samostatně se připravil na pohybovou aktivitu a vhodným způsobem ji ukončil, předvídal možná nebezpečí úrazu, tvořivě aplikoval získané dovednosti, posoudil provedení pohybové činnosti, označil případné nedostatky a jejich možné příčiny, dohodl se na spolupráci a taktice atd. (Rámcový vzdělávací program pro základní vzdělávání, 2007, s. 77 - 78).

Hlubší analýza vyučovacích jednotek TV (viz obrázek 3, 4, 5 a 6 a tabulka 4) ukázala, že se objevila jediná skupina se statisticky významnějším rozdílem (učitelé 5 - 10 let praxe, viz tabulka 4). Na základě tohoto zjišsění se lze domnívat, že zastoupení jednotlivých DŘS ve vyučovacích jednotkách v námi realizovaném výzkumu významně neovlivnila ani délka praxe učitele (jeho profesní zkušenost), ani pohlaví učitele nebo pohlaví žáků, kteří se vyučovací jednotky TV zúčastnili, a ani velikost školy (tedy její prostředí a potenciálně materiální zabezpečení pro výuku TV). Tato zjištění lze využít při hledání odpovědí na to, jaké další faktory kromě didaktických mohou ovlivňovat zastoupení jednotlivých DŘS ve výuce. 


\section{LITERATURA}

Bryant, L.G., \& Curtner-Smith, M.D. (2008). Impact of a Physical Education Teacher's Disability on Elementary Pupils' Perceptions of Effectiveness and Learning. Adapted Physical Activity Quarterly, 25(2), 118 - 131.

Bryant, L.G., \& Curtner-Smith, M.D. (2009a). Effect of a physical education teacher's disability on high school pupils' learning and perceptions of teacher competence. Physical Education and Sport Pedagogy, 14(3), $311-322$.

Bryant, L.G., \& Curtner-Smith, M.D. (2009b). Influence of a physical education teacher's disability on middle school pupils' learning and perceptions of teacher competence. European Physical Education Review, 15(1), 5 $-19$.

Cothran, D.J. et al. (2005). A Cross-Cultural Investigation of the Use of Teaching Styles. Research Quarterly for Exercise and Sport, 76(2), 193 - 201.

Curtner-Smith, M.D. (2001). Instrument for Identifying Teaching Styles. Dostupné z http://www.spectrumofteachingstyles.org/pdfs/literature/CurtnerSmith2001_IFITS.pdf

Curtner-Smith, M.D., Hasty, D.L., \& Kerr, I.G. (2001). Teachers' use of productive and reproductive teaching styles prior to and following the introduction of National Curriculum Physical Education. Educational Research, 43(3), $333-340$.

Curtner-Smith, M.D., Todorovich, J., McCaughtry, N., \& Lacon, S.A. (2001). Urban teachers' use of productive and reproductive teaching styles within the confines of the National Curriculum for Physical Education. European Physical Education Review, 7(2), 177 - 190.

Dobrý, L. (1988). Didaktika sportovnich her. Praha: SPN.

Dobrý, L. (2007). Změna činnosti učitele je hlavní podmínkou úspěchu naší školské reformy. Tělesná výchova a sport mládeže: odborný časopis pro učitele, trenéry a cvičitele, 73(3), 8 -15.

Goldberger, M. (2011). The Spectrum of Teaching Styles - Revisited 2011. Dostupné z http://www.jmu.edu/ kinesiology/pdf/Spectrum\%20article\%20(2).pdf

Hercig, S. (1994). Alternativy tělesné výchovy. Tělesná výchova a sport mládeže, 60(8), 2 - 6.

Janík, T., \& Miková, M. (2006). Videostudie: výzkum výuky založený na analýze videozáznamu. Brno: Paido. Janíková, M., Janík, T., \& Kamírová, E. (2009). Vyučovací jednotky tělesné výchovy z hlediska organizačních forem a fází výuky. In Mužík, V., \& Süss, V. (Ed.), Tělesná výchova a sport mládeže v 21. století (s. 100 - 114). Brno: Masarykova univerzita.

Janíková, M., Janík, T., Mužík, V., \& Kundera, V. (2008). CPV videostudie tělesné výchovy: sběr dat a zamýšlené analýzy. Orbis scholae, 2(1), 93 - 114.

Mareš, J., Průcha, J., \& Walterová, E. (2003). Pedagogický slovník. Praha: Portál.

Mosston, M., \& Ashworth, S. (2008). Teaching Physical Education: First Online Edition. Dostupné $\mathrm{z}$ http://www.spectrumofteachingstyles.org/ebook

Parker, M., \& Curtner-Smith, M.D. (2012). Preservice teachers' use of production and reproduction teaching styles within multi-activity and sport education units. European Physical Education Review, 18(1), 127 - 143.

Průcha, J. (2006). Přehled pedagogiky. Praha: Portál.

Rámcový vzdělávaci program pro základni vzdělávání (2007). Praha: Výzkumný ústav pedagogický. Dostupné z http://www.vuppraha.cz/wp-content/uploads/2009/12/RVPZV-pomucka-ucitelum.pdf

Rychtecký, A., \& Fialová, L. (2004). Didaktika školni tělesné výchovy. Praha: Karolinum.

Tomajko, D., \& Dobrý, L. (2002). Didaktické styly a metodicko-organizační formy jako základ vyučování pohybových her. Tělesná výchova a sport mládeže: odborný časopis pro učitele trenéry a cvičitele, 68(4), 26 - 33. Vilímová, V. (2002). Didaktika tělesné výchovy. Brno: Paido.

Vlček, P. \& Mužík, V. (2012). Soulad mezi projektovaným a realizovaným kurikulem jako faktor kvality vzdělávání v tělesné výchově. Česká kinantropologie, 16(1), 21 - 35. 